\title{
SABAR DALAM HADIS
}

\author{
M. Idman Salewe \\ Ma'had Aly As‘adiyah Sengkang \\ Jl. Andi Unru Jalur 2 Sempangnge, Desa Ujung Baru, Kecamatan Tanasitolo \\ Kabupaten Wajo, 90951, Sulawesi Selatan, Indonesia \\ Email: Idmansalewe@ymail.com
}

\begin{abstract}
This article discourse about the meaning of patient, as well as the concept of patience in hadith. The discussion conducted by using mawdī' $\bar{\imath}$ method and takhrij method throughpronunciations, which collects hadith from word sabara or or other keywords related to it. Author found that hadith about the patient classified as a weak hadith, because there was a narrator who mubham. From the aspect of matan, hadith on patient does not contain syäz and 'illah. Patient is a struggle that illustrates the power of the soul culprit (controlling) the passion of lust, so that for every Muslim having the character of patient in anycircumstances. Patient has a close aspect with faith, piety, and good deeds. A patient is someone who is optimistic in facing of difficulties and problems in their life. A patient people are those who fear to Allah, and those who continue to be active in doing good deeds is a piety one.
\end{abstract}

Keywords: The Patient, Mawdī ‘ì, Takhrīj

\begin{abstract}
Abstrak
Artikel ini membahas tentang makna sabar, serta konsep sabar dalam hadis Nabi Muhammad Saw. Pembahasan dilakukan dengan menggunakan metode mawdī ‘̀ dan takhrīj melalui lafal-lafal hadis, yaitu mengumpulkan hadis-hadis yang memiliki kata kunci șabara atau terkait dengannya. Penulis menemukan bahwa hadis tentang sabar tergolong hadis daif, karena ada rawi yang mubham. Dari aspek matan, hadis tentang sabar tidak mengandung syäż dan 'illah. Sabar adalah perjuangan yang menggambarkan kekuatan jiwa pelakunya (mengendalikan) keinginan hawa nafsu, sehingga sifat sabar bagi setiap muslim terletak pada situasi dan kondisi apa pun. Sabar memiliki aspek yang erat dengan iman, takwa, dan amal saleh. Seorang penyabar, adalah orang yang optimis dalam menghadapi kesulitan dan problematika kehidupan. Orang-orang sabar adalah mereka yang bertakwa, dan yang termasuk dalam kategori bertakwa adalah mereka yang senantiasa aktif melakukan amal saleh.
\end{abstract}

Kata Kunci: Sabar, Mawdī ‘ì, Takhrīj

\section{Pendahuluan}

Sejalan dengan perkembangan dan kemajuan yang cepat manusia dalam kehidupan di zaman modern yang penuh tantangan dan kompetitif dalam berbagai aspek, setumpuk masalah berat dan ringan yang memerlukan solusi atau pemecahan masalah yang bukan saja membutuhkan kekuatan otot dan otak tetapi lebih dari itu dengan aspek mentalitas yang tenang, sejuk dan mantap mungkin disebut dengan karakter sabar. Seperti dikatakan dalam slogan ekonomi bahwa hidup adalah kebutuhan. Sejak lahir manusia diperhadapkan dengan kebutuhan, sejak itu pula manusia berhadapan dengan masalah faktor pemenuhan kebutuhan kebutuhan tidak pernah akan habis dan selesai, karena setelah pemenuhan pertama akan muncul 
kebutuhan berikutnya demikian sampai akhir hayat.

Seperti dikabarkan Alquran tentang hidup ini adalah perjuangan dan karena perjuangan itu berarti kesulitan. Kesulitan itu tidak akan berakhir sampai penghujung kehidupan seorang di dunia ini, seperti dijelaskan dalam surah al-Balad ayat 4 sebagai berikut:

$$
\text { كَقَلْ خَلَقْنَا آلْإِنسنَ فِنَ كَبَدِ }
$$

Sesungguhnya Kami telah menciptakan manusia berada dalam bersusah payah.

Setelah manusia mampu menghadapi berbagai faktor kesulitan hidup ini dari aspek kebutuhan pemenuhan kebutuhan hidup, maka secara imaniah masih menghadapi aspek yang kurang dahsyatnya. Misalnya, orang-orang yang sudah mampu meraih dengan berbagai jenis fasilitas kehidupan yang memadai, ternyata masih dihadang yang namanya beruntungan, kecelakaan, kerugian dalam hal-hal tertentu walau sudah maksimal upaya ikhtiar yang dilakukan. Mungkin ini yang diyakini sebagai orang yang beriman adalah cobaan, musibah, ujian atau sekaligus hukuman atas berbagai jenis pelanggaran (dosa) dalam hal ini pada gilirannya sebagai orang beriman dibekali dengan potensi sabar (kesabaran).

Dengan kesabaran, berbagai tantangan hidup, persoalan kehidupan, antisipasi pemenuhan kebutuhan yang tidak akan pernah berakhir sampai akhir hidup di dunia, cobaan, ujian, musibah dan hukuman kerena pelanggaran dapat dihadapi dan dilalui dengan tenang dan aman selamat karena kesabaran. Hal ini Allah Swt. sudah memberi tuntunannya dalam Alquran surah al-Baqarah ayat 153 sebagai berikut:

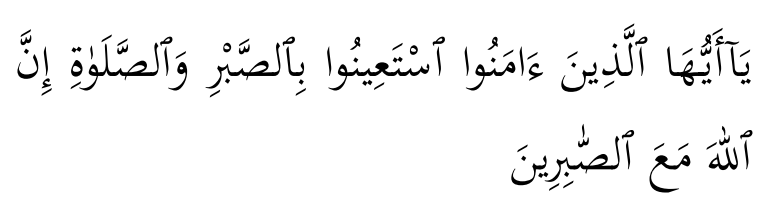

Hai orang-orang yang beriman, jadikanlah sabar dan shalat sebagai penolongmu Sesunggunya Allah beserta orang-orang yang sabar.

Berdasarkan latar belakang di atas, maka penulis mengangkat pokok pembahasan yakni masalah sabar dalam perspektif hadis dengan memberikan batasan-batasan sebagai berikut: Bagaimana hakikat sabar secara etimilogi maupun terminologi? Bagaimana konsep sabar menurut menurut ulama hadis, ulama tafsir dan lainnya?

\section{Metode dan Pendekatan}

Pembahasan mengenai sabar dalam perspektif hadis Nabi ini menggunakan metode mawdī ' $\bar{l}$, di mana penulis berusaha mengumpulkan hadis-hadis yang memiliki kata kunci șabara atau terkait dengannya. Hadis-hadis tersebut kemudian diklasifikasi berdasarkan tema kajian untuk dilakukan takhrijj terhadap hadis yang masih menjadi 
bahan perdebatan kesahihannya di kalangan ulama agar diketahui tingkat kualitas hadis tersebut. Langkah selanjutnya adalah menggali makna hadis tersebut dalam kitabkitab syarah hadis serta membandingkan pemahamannya dengan para ulama tafsir. Terakhir adalah mengambil kesimpulan berdasarkan berbagai pandangan di atas.

\section{Takhrïj Hadis}

Secara leksikal takhrīj berarti keluar, nampak jelas dan lain-lain. Dalam hal ini makna takhrīj yang popular digunakan ulama ialah al-istimbat (hal mengeluarkan), al-tadrīb (hal melatih) dan al-tawjīh (hal menghadapkan atau menjelaskan).

Adapun takhrīj menurut terminologi ulama hadis adalah: Pertama, menyebutkan hadis serta sanadnya, mendiskusikan keadaan sanad dan matannya seperti yang terdapat dalam kitad Sunan al-Tirmiż̀̄ dan Sunan Abū Dāwud. Kedua, menyebutkan jalur sanad lainnya untuk memperkuat sanad hadis yang terdapat dalam suatu kitab. Ketiga, mengembalikan hadis kepada kitab-kitab aslinya dengan menjelaskan kualitasnya. Penulis maksud dengan takhrīj hadis di sini adalah mengeluarkan hadis dari sumber aslinya dengan mencantumkan sanad dan matannya kemudian menjelaskan kualitas hadis tersebut.
Ada 5 metode yang ditawarkan ulama hadis dalam pelaksanaan takhrīj hadis yakni berdasarkan kitab-kitab kumpulan hadis, lafal-lafal hadis, rawi pertama, tema-tema hadis dan ciri-ciri tertentu. Dalam pelaksanaan takhrīj kali ini penulis menggunakan metode takhrīj melalui lafal-lafal hadis dengan menggunakan kitab al-Mu 'jam al-Mufahras li Alfāz al-Hadīis dan CD program Kutub Tis'ah.

Adapun yang menjadi kata kunci dalam penelitian ini adalah kata șabara di samping melacak kata-kata lain yang terkait dengannya. Setelah melalui penelusuran dalam kitab-kitab al-Mu jam al-Mufahras $l i$ Alfāz al-Hadīis al-Nabawī dan CD program Kutub Tis'ah, ditemukan beberapa tema yang berbicara tentang sabar.

\section{Klasifikasi Hadis Sabar}

1. Sabar Ditunjukkan dari Sikap Pertama atas Suatu Kejadian

a. Hadis riwayat al-Bukhārī, kitab Janā'iz, bab Ziyārah al-Qubr, No. 1203:

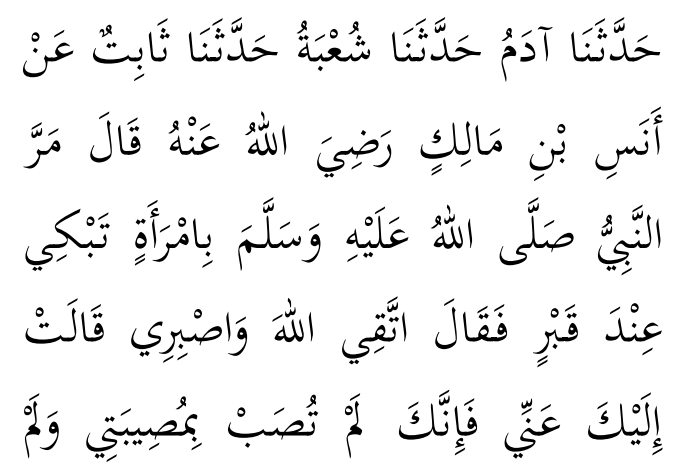




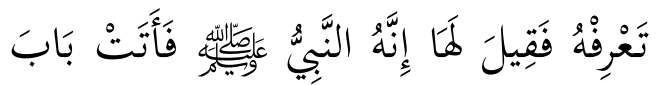

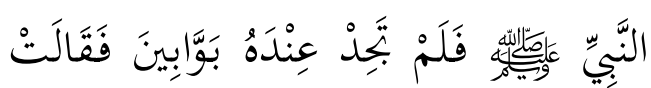

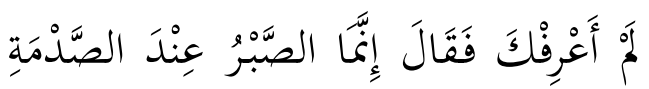

b. Hadis riwayat al-Bukhārī, kitab alJanā'iz, bab al-Șabr 'inda al-Șadmah al- $\bar{l} l \bar{a}:$

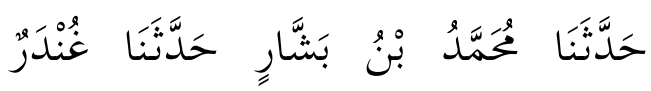

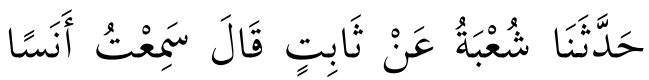

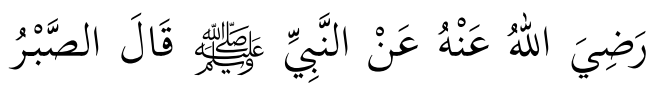

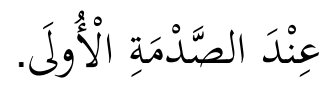

c. Hadis riwayat Muslim, kitab alJanā'iz, bab F̄̄ al-Ṣabr 'inda alȘadmah al-Ūlā, no. 1534:

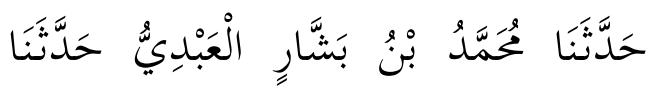

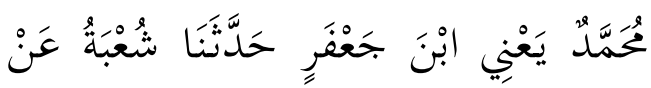
ثَابِتِ قَالَ سَمِفْتُ أَنَسَ بْنَ مَالِلكٍ ِيَقُولا

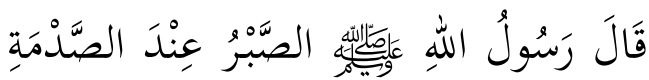

d. Hadis riwayat al-Tirmiżī, kitab alJanā'iz, bab mā jā'a anna al-Ṣabr 'inda al-Ṣadmah al-Ūlā, no. 908:

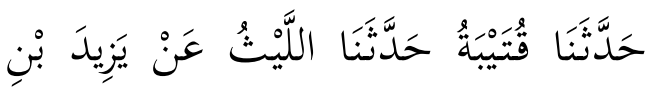
أَبِي حَبِيبٍ عَنْ سَعْدِ بْنِ سِنَانٍ عَنْ أَنَسِ

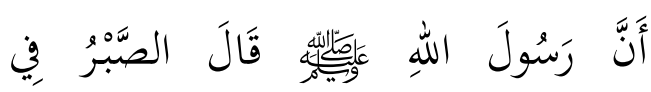

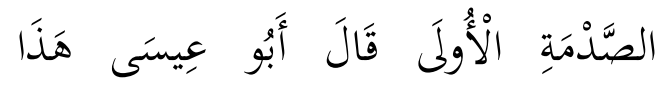

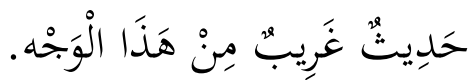

e. Hadis riwayat al-Nasā'̄ Janā'iz, bab al-Amr bi al-Ihtisāâi wa al-Ṣabr 'inda Nuzūli al-Ṣadmah, no. 1816:

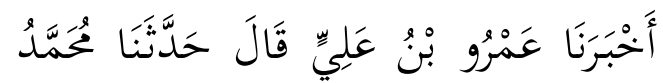

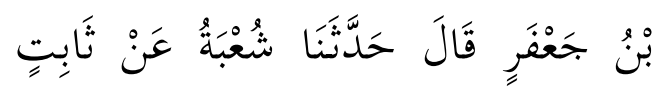

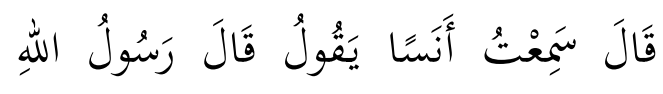

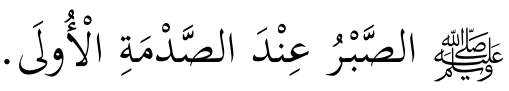

f. Hadis riwayat Abū Dāwud, kitab alJanā'iz, bab al-Șabr 'inda al-Ṣadmah, no. 2717:

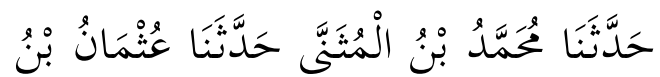

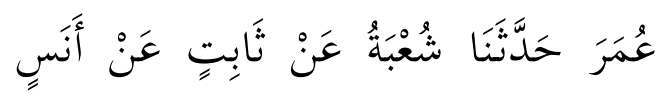

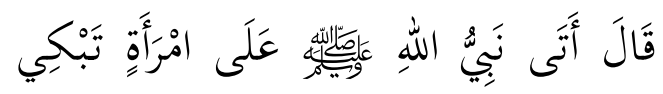

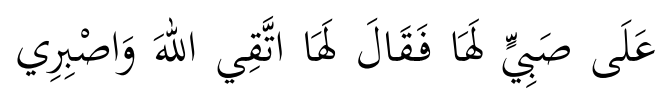

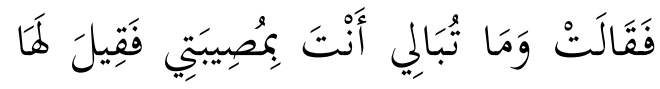

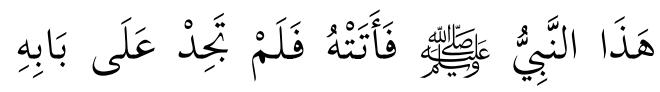

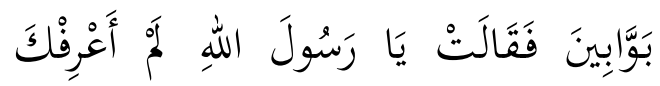

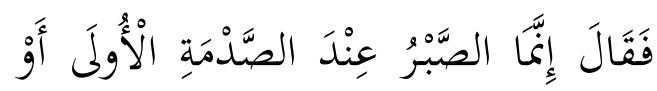
عَعْدَ أَوَّلِ صَدْمٍَِ.

g. Hadis riwayat Ibn Mājah, kitab alJanā'iz, bab Mā jā'a fì al-Ṣabr 'alā al-Ma șiyah, no. 1585: 


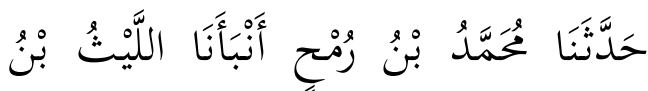

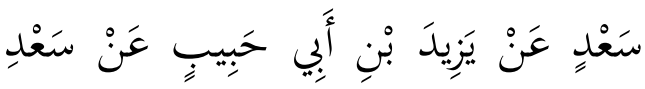

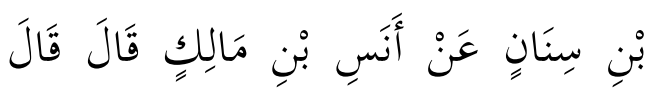

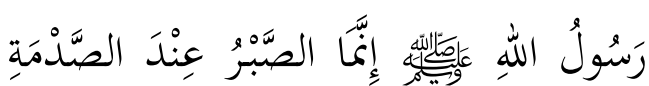
انالْوُلَّ.

h. Hadis riwayat Aḥmad Ibn Hanbal, kitab Bāqū Musnad al-Muksiriñn, bab Musnad Anas bin Mālik, no. 12003:

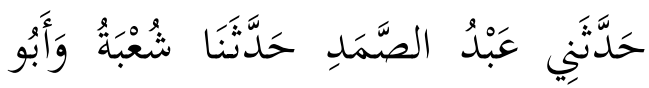

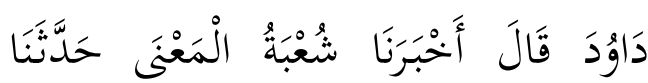

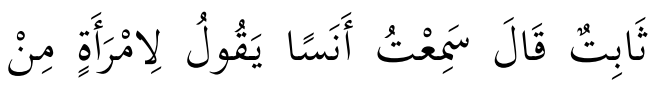

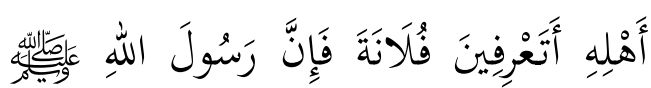

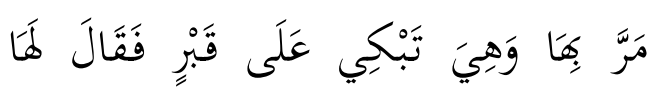

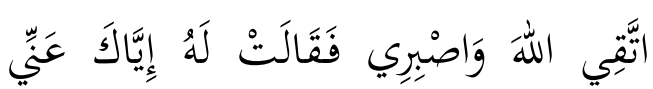

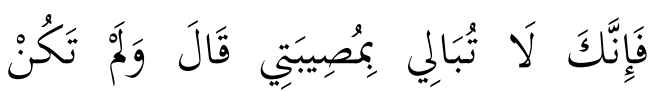

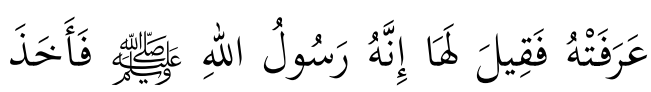

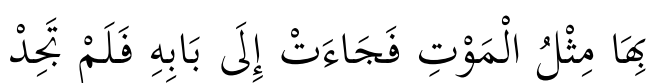

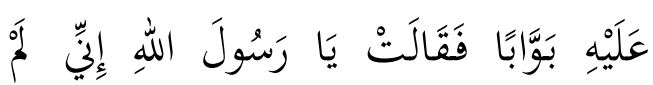

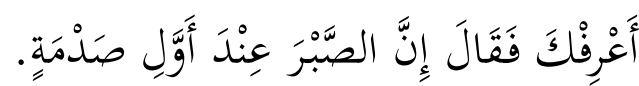

2. Sabar Terhadap Hal yang Diharamkan Allah

a. Hadis riwayat al-Bukhārī, kitab alRiqāq, bab al-Sabr 'an Maḥārimillāh, no. 5989:

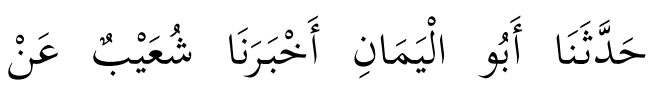

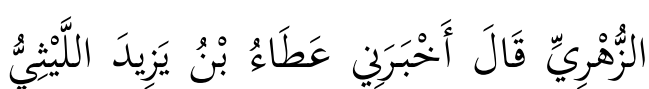

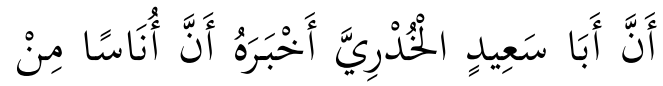

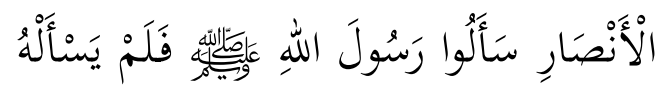

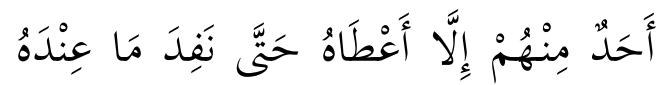

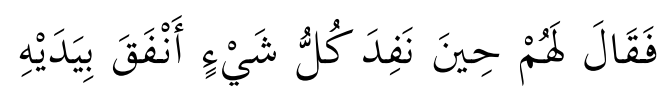

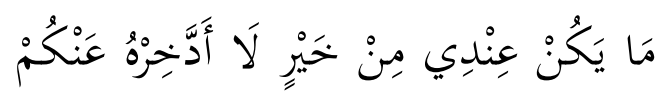

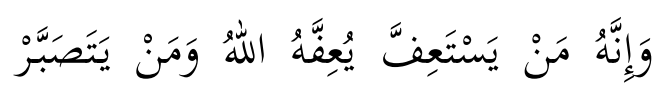

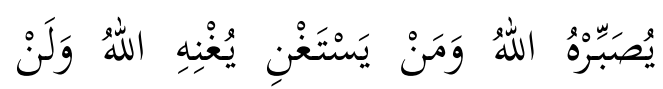

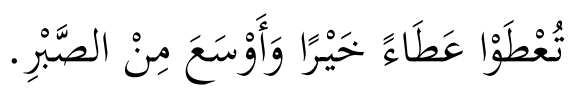

b. Hadis riwayat Mālik, kitab al-Jāmi , bab Mā Jā'a fí al-Ta'affufí 'an alMas'alah, no. 1585:

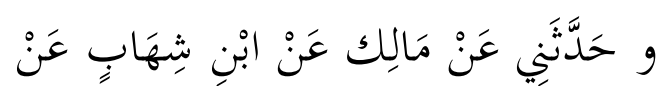

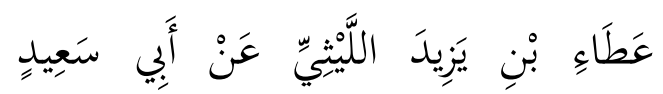

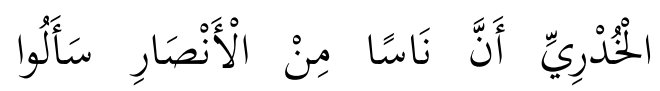

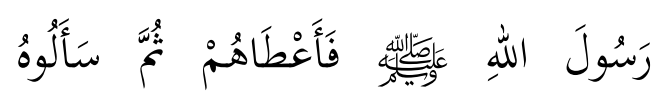

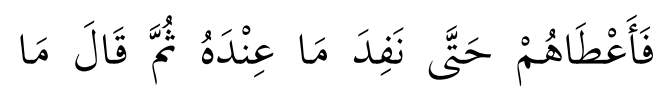

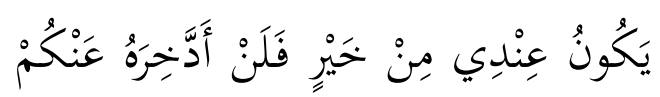

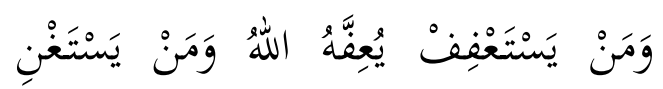

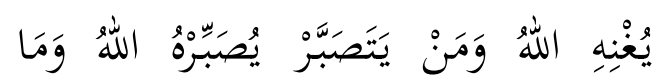

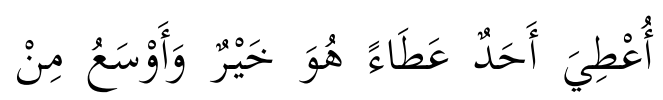
الصَّبْر.

c. Hadis riwayat al-Dārimī, kitab Zakāh, bab Fì al-Isti 'fāf 'an al-Mas'alah:

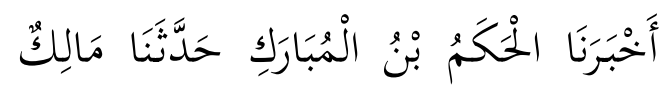

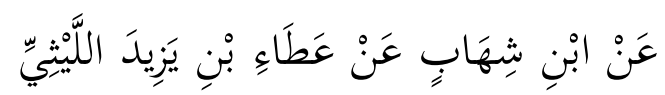


عَنْ أَبْي سَعِيدٍ المُحْرِيِّ أَنَّ نَاسًا مِنْ

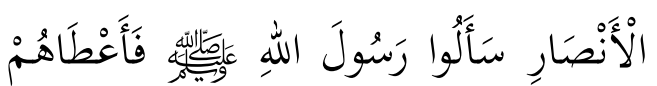

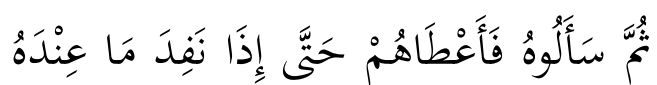

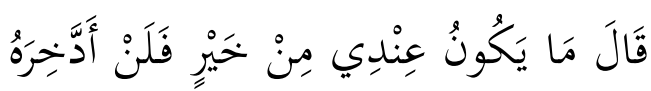

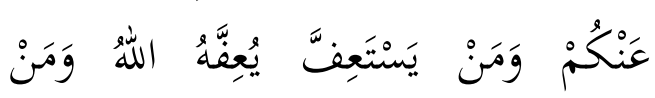

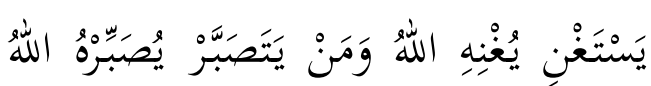

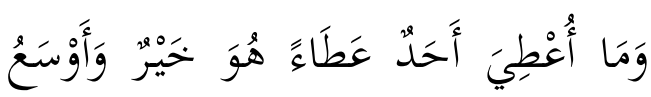

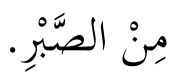

\section{Puasa Setengah dari Sabar}

a. Hadis riwayat al-Tirmiżī, kitab alDa'awāt 'an Rasūlillāh, bab Minhu, no. 3441 :

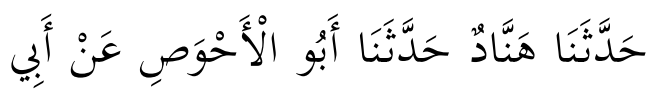

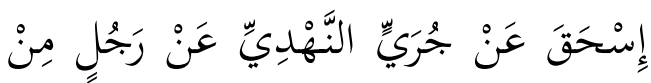

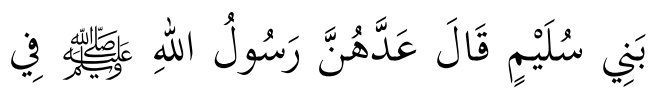

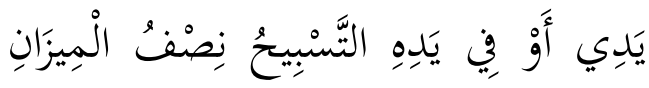

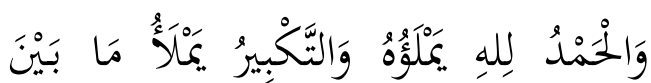

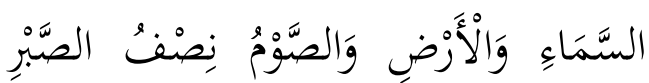

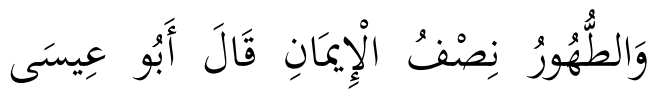

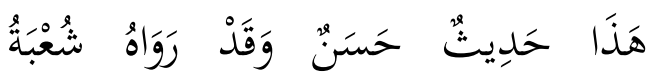
وَسُفْيَانُ النَّوْرِيُّ عَنْ أَبْي إِسنحَقَّ.

b. Hadis riwayat kitab Musnad Ahmad bin Hanbal, kitab Bāqĩ Musnad alAnșār, bab Aḥādīs Rijāl min Aṣhāb al-Nabī, no. 22078:

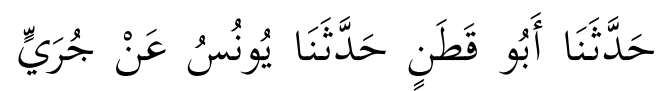

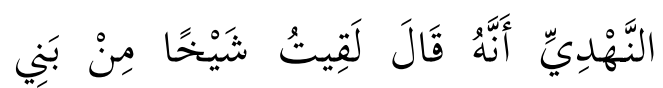

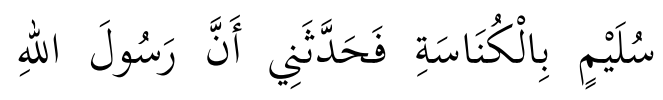

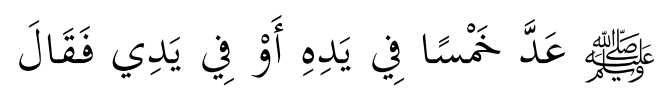

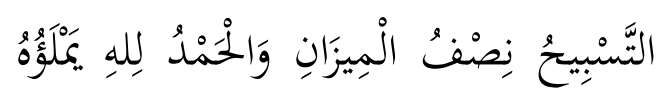

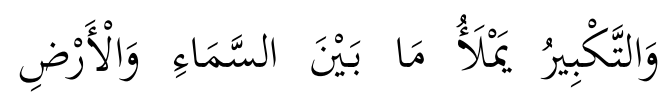

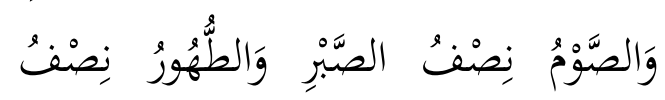
الإِيمَانِ.

c. Hadis riwayat kitab Sunan al-Dārimī, kitab Tahārah, bab Mā Jā'a fí alTahüri, 652:

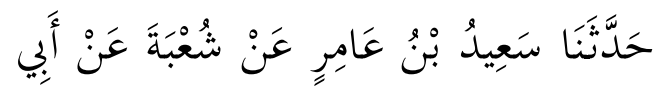

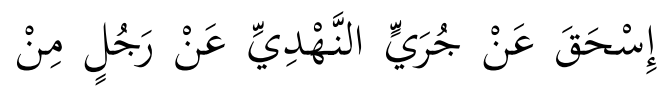

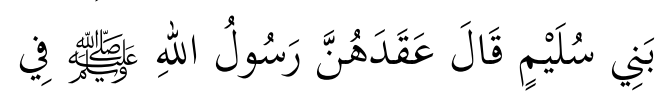

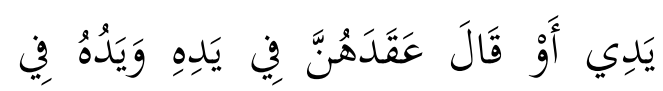

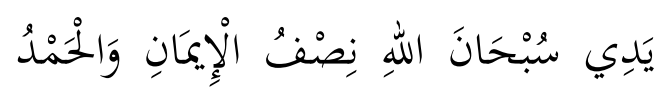

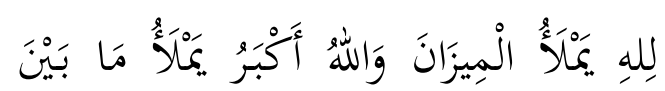

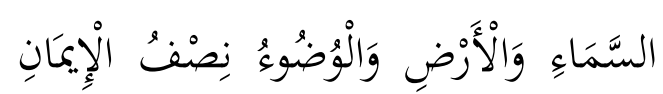
وَالصَّومُ نِصْفُ الصَّبْرِ.

d. Hadis riwayat Ahmad bin Hanbal, kitab Bāqu Musnad al-Anșār, bab Aḥādīs Rijāl min Aṣhāb al-Nabī, no. 22058:

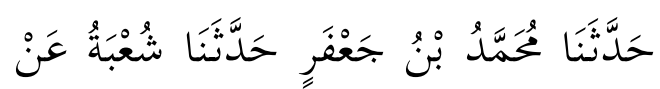

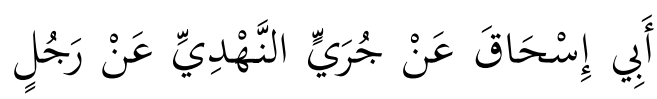

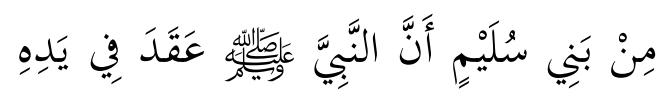




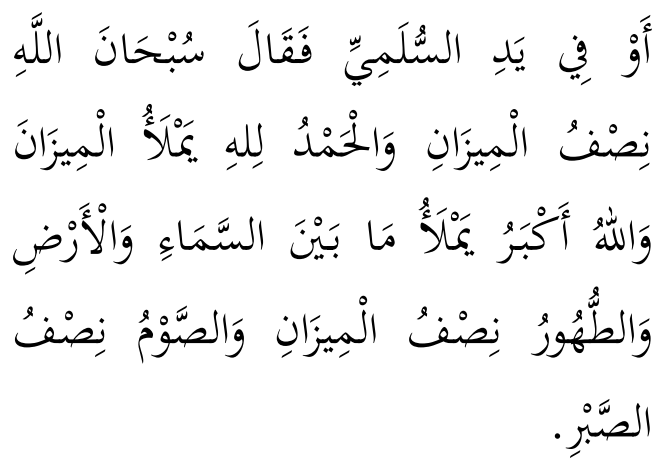

\section{I'tibār Hadis}

Setelah dilakukan pengklasifikasian hadis berdasar tema yang terdapat dalam Kutub Tis'ah maka langkah berikutnya adalah melakukan i'tibār yakni meneliti semua jalur hadis yang memiliki teks yang sama (bi al-lafži) maupun maknanya serupa (bi al-ma'nā) untuk melihat ada tidaknya pendukung (corraboration) berupa periwayat yang berstatus syāhid (pendukung pada tingkat sahabat) atau mutābi' (pendukung bukan dari sahabat) atau hadis tersebut menyendiri (fard). ${ }^{1}$
Dengan ditemukannya jalur periwayat lain baik yang berstatus sebagai syāhid maupun mutābi ' akan semakin menguatkan kedudukan hadis tersebut. Apabila jalur periwayat yang semula berstatus $d a$ 'îf, misalnya, maka derajatnya dapat naik menjadi hasan li gayrihi atauapabila jalur sanadnya yang semula berstatus hasan, dengan adanya syāhid atau mutābi" maka hadis tersebut dapat naik statusnya menjadi hadis șaḥiḥ li gayrihi. ${ }^{2}$ Karenanya, i'tibār mesti dilakukan untuk mengetahui tingkat akurasi periwayatan hadis.

Dalam hal ini, jalur sanad hadis yang menjadi fokus i'tibār adalah hadis yang berkaitan dengan "puasa setengah dari sabar" karena hadis ini tidak ditemukan dalam riwayat al-Bukhārī dan Muslim.

Berikut adalah skema $i$ 'tibār hadis tersebut.
${ }^{1}$ Muhạammad 'Ajjāj al-Khațīb, Ușūl al-Hadìs: 'Ulūmuhu wa Muștalaḥuh (Beirut: Dār al-Fikr, 1989), 367.

\footnotetext{
${ }^{2} \mathrm{Al}-\mathrm{Khațịb}, U s \underline{u} \mathrm{u}, 170$.
} 


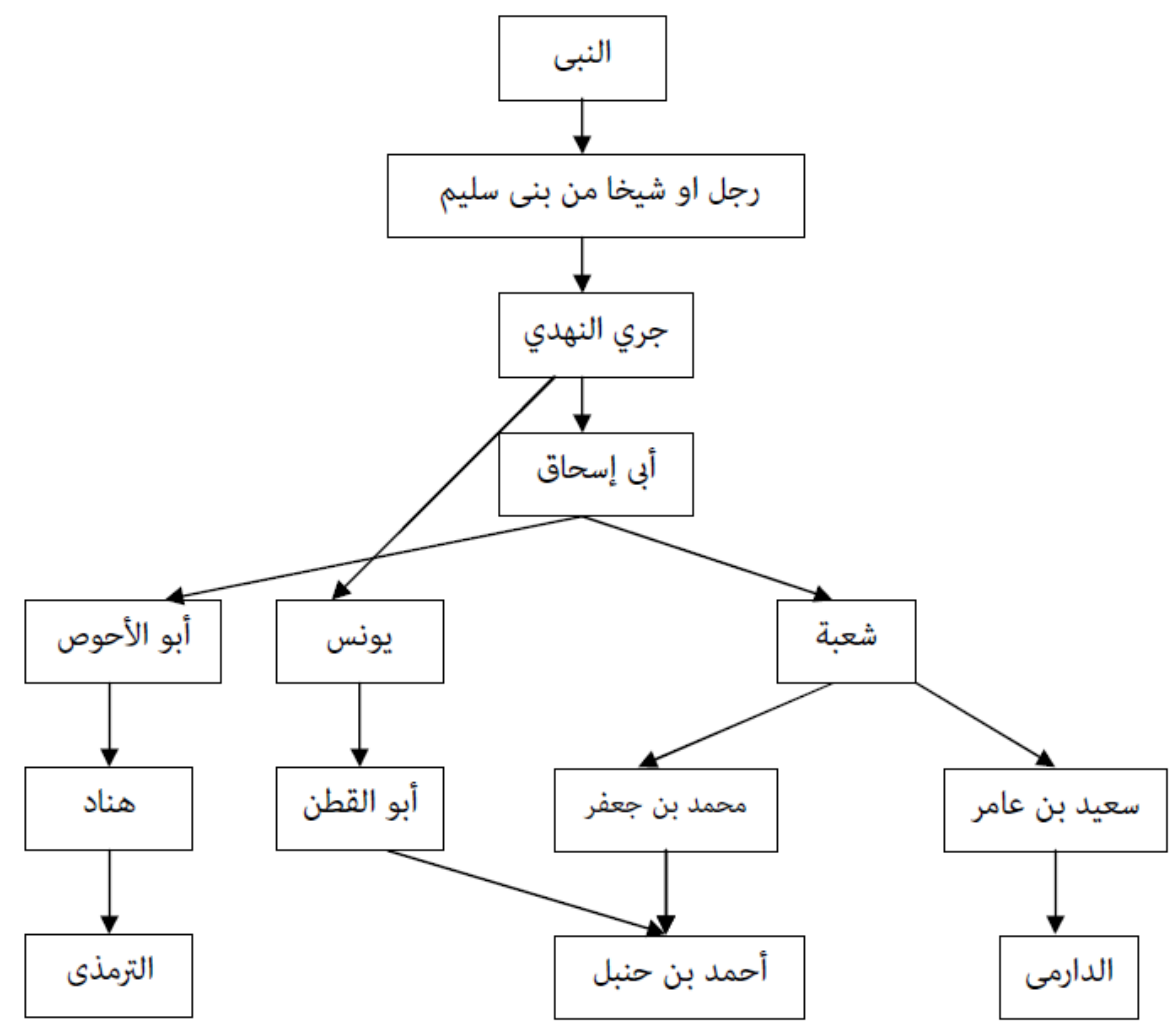

Skema

Sanad Hadis Puasa Setengah Dari Sabar

Berdasarkan skema jalur sanad hadis di atas dapat disimpulkan:

1. Tidak ditemukan jalur periwayatan yang berkedudukan sebagai syāhid sebab pada perawi sahabat hanya ditemukan seorang perawi pada semua jalur sanad.

2. Terdapat mutābi $i^{\star}$ pada jalur periwayatan al-Tirmiż̄i dan al-Dārimī pada perawi di tingkat keempat yakni Abū al-Aḥwaṣ dengan mutābi Syu'bah.

Adapun lambang yang digunakan عن dalam seluruh jalur periwayatan adalah dan حدثنا. Sedang matan hadis tersebut diriwayatkan secara maknawi.

\section{Kritik Sanad Hadis}

Dalam kaidah kesahihan hadis dinyatakan bahwa syarat hadis yang dinilai sahih apabila memenuhi lima kriteria, ${ }^{3}$ yakni:

\footnotetext{
${ }^{3}$ Menurut Șubḥī al-Ṣaliḥ, hadis sahih adalah hadis musnad yang bersambung sanadnya dengan perawi yang adil lagi $d \bar{a} b i t$ dari perawi yang adil lagi dāabit pula. Semua perawi tersebut sampai kepada Nabi atau sahabat atau tabiin dan tidak terdapat syāż serta 'illah. Lihat Șubḥ̄i al-Ṣāliḥ, 'Ulūm al-Hadìs wa Muștalahuh (Beirut: Dār al-'Ulūm li al-Malāyīn, 1988), 145
} 
1. Apabila sanad hadis tersebut bersambung mulai dari mukharrij-nya sampai kepada Nabi.

2. Seluruh perawi pada jalur sanad tersebut bersifat adil.

3. Seluruh perawi bersifat dāaitit.

4. Tidak terdapat $s y \bar{a} \dot{z}$.

5. Tidak terdapat 'illah.

Dengan kriteria di atas dapat dinilai tingkat kualitas suatu hadis. Apabila suatu hadis memenuhi semua kriteria tersebut maka ia dinilai sahih namun bila salah satu kriteria tidak terpenuhi maka akan dinilai daif. Untuk mengetahui kualitas persambungan sanad dan keadilan serta keḍābitan para perawinya dilakukan penelitian tentang biografi perawi. Berikut akan dipaparkan mengenai biografi perawi hadis yang menjadi fokus penelitian.

\section{Biografi Para Perawi Hadis}

Dalam menilai kualitas ketersambungan sanad hadis mulai dari perawi awal sampai pada mukharrij hadis, ulama mengandalkan kitab-kitab biografi perawi hadis. Ketersambungan sanad dapat ditentukan melalui tahun lahir dan wafat seorang perawi, tempat tinggalnya, perjalanannya dalam menuntut ilmu dan yang penting juga adalah hubungan guru dan murid antar perawi hadis. Sedang keadilan dan keḍābitan perawi didapat dari informasi penulis kitab biografi perawi tentang sifat, sikap dan kemampuan daya ingatnya selama meriwayatkan hadis.

Untuk memudahkan penelitian dan menilai kualitas para perawi hadis, penulis berusaha meringkasnya dalam sebuah bagan yang berisi informasi data-data perawi yang diambil dari CD Program Hadis Kutub Tis'ah. Namun untuk tujuan efisiensi halaman, perawi yang kembali terdapat pada jalur hadis lain, tidak diungkapkan kembali informasi biografinya pada jalur hadis berikutnya.

Berikut adalah biografi semua perawi hadis yang tengah diteliti: 


\begin{tabular}{|c|c|c|c|c|c|c|}
\hline و التعديل & تلميذ & شيخ & ترجمة & 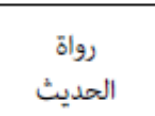 & المخرج & فمرة \\
\hline 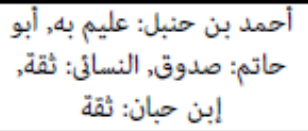 & إمام الترمذي & أبو بكر بن عياش بن سام & كـــناد بن الرى بن مصعبر. & هــــاد & \multirow[t]{5}{*}{ الترمذى } & \multirow[t]{5}{*}{1} \\
\hline 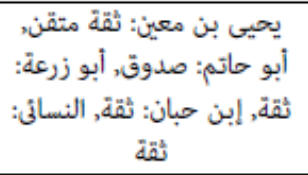 & هــناد بن الرى بن & شعث بن إبى الشعثاء & ســلام بن سـليم, كبار الأتباع, & أبو الأحوص & & \\
\hline 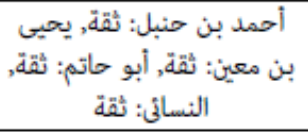 & أبو بكر بن عياس بن & أبو حنيفة & 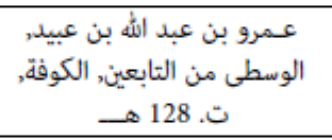 & إبو إسحاق & & \\
\hline مقبول & عمرو بن عبد الله بن & على بن أبى طالب & جرى بن كليب, الوسطى من التابعين, الكوفة, & جرى النهدي & & \\
\hline إسم مبهم & إسم مبهم & إسم مبهم & إسم مبهم & بنى سليم من & & \\
\hline 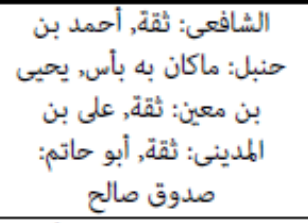 & عبد الله بن مسعود & حمزة حبيب بن عمارة & 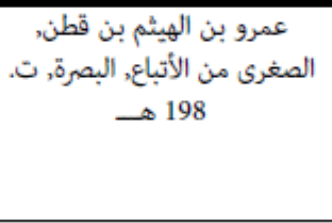 & أبو قطن & \multirow[t]{4}{*}{ حنبل } & \multirow[t]{4}{*}{2} \\
\hline حاتم: صدوقى بن معني: ثقة", أبو حبان: & عمرو بن الهيثم بن & إبراهيم بن سعد بن عبد & الصغرى من الأتباعر بغداد, بن مسلم, & يونس & & \\
\hline- & - & - & - & جري النهدي & & \\
\hline - & - & - & - & شنيخ من سليم & & \\
\hline 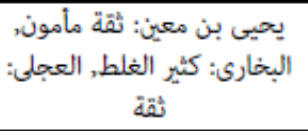 & أحد شيخ الإمام & أسماء بن عبيدة بن & سعيد بن عامر & ع عامر بن & \multirow[t]{5}{*}{ الدارمى } & \multirow[t]{5}{*}{3} \\
\hline ففيان الثورى: أمير المؤمنين & سعيد بن عامر & إبراهيم بن محمد بن & كبار الأتباع, البصرة, تـ الحجاج بن الورد, 160 هـ & شـعبة & & \\
\hline 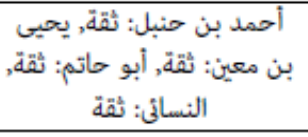 & أبو بكر بن عياس بن & أبو حنيفة & الوسطى من التابعين, الكوفة, عبدر, & أبو إسحاق & & \\
\hline - & - & - & - & 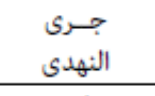 & & \\
\hline - & - & - & - & بنى سـليم من & & \\
\hline
\end{tabular}




\begin{tabular}{|c|c|c|c|c|c|c|}
\hline 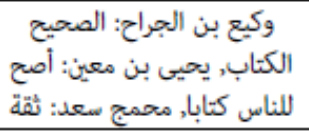 & عبد الله شين محمد بن & إسرائيل بن يونس بن إبى & محمد بن حعفر & معمد بن & \multirow[t]{5}{*}{ حنبل } & 4 \\
\hline - & - & - & - & شعبة & & \\
\hline - & - & - & - & أبو إسحاق & & \\
\hline - & - & - & - & جرى النهدي & & \\
\hline- & - & - & - & بنى سليلم & & \\
\hline
\end{tabular}

Tabel

Biografi Perawi Hadis Puasa Setengah Dari Sabar

\section{Analisa Kualitas Sanad}

Dalam analisis hadis, dari empat hadis dengan tema "puasa setengah dari sabar", penulis hanya melakukan analisis sanad dan matan dari riwayat al-Tirmiżī. Berdasarkan data biografi para perawi yang telah dipaparkan pada bagan di atas dapat disimpulkan:

Al-Tirmiżī sebagai mukharrij hadis menerima dari Hannād. Antara al-Tirmiżī dan Hannād terjadi ketersambungan sanad karena keduanya berkedudukan sebagai murid dan guru dan dari segi usia dimungkinkan keduanya bertemu. Dari segi keadilan dan keḍābitan (gabungan keduanya sering disebut dengan siqah), berdasarkan data biografi perawi di atas menunjukkan bahwa Hannād dinilai siqah, $s ̧ a d \bar{u} q$ dan bentuk keadilan lainnya.

Pada perawi berikutnya yakni Abū al-Aḥwaṣ juga terjadi ketersambungan dengan Hannād karena adanya hubungan guru dan murid sedang dari segi keadilan, para pengkritik perawi menilai Abū alAḥwaṣ sebagai siqqah mutqin, șadūq dan penilaian positif lainnya.

Abū Ishạāq dan Juray al-Nahdī juga dinilai siqah dan maqbūl sehingga diterima keadilannya. Sedang segi persambungan sanadnya, ada kemungkinan antara keduanya dan perawi sebelumnya bersambung dilihat dari segi usia.

Adapun sanad terakhirnya adalah "rajul bin bani Sulaym” dinilai oleh para kritikus sebagai mubham karena tidak dikenal siapa orangnya. Karena itu tidak bisa dinilai kesiqahan dan ketersambungan sanadnya. Apakah perawinya termasuk dari perawi daif atau siqah.

\section{Analisa Kualitas Matan}

Kualitas kesahihan hadis tidak hanya ditentukan oleh kualitas sanadnya namun juga kualitas matannya. Karenanya sanad yang sahih tidak mesti memiliki matan yang juga sahih. Penelitian sanad 
berbeda dengan penelitian matan. Bila sanad didasarkan pada kualitas para perawi dari sisi keadilan dan keḍābiṭannya sedang kualitas matan ditentukan oleh kandungan hadis tersebut apakah bertentangan dengan dalil yang lebih kuat lagi atau biasa disebut dengan syā̇z atau tidak. Bila ditemukan adanya dalil yang lebih kuat periwayatannya dan kandungannya bertentangan dengan hadis yang jalur periwayatannya juga sahih namun kualitasnya berada di bawah hadis tersebut maka ia dinilai daif karena syā̇z. Di samping terdapat tidaknya syāż, dalam makna hadis tersebut juga perlu dinilai apakah ada unsur 'illah yakni memuttașilkan hadis yang mestinya mursal dan mawqūf atau tidak. ${ }^{4}$

Sejauh pelacakan yang penulis lakukan baik dalam kitab hadis maupun Alquran tidak ditemukan dalil yang bertentangan dengan kandungan hadis tersebut secara eksplisit. Sedang adanya unsur 'illah hadis dalam matan hadis tersebut, tidak ada seorang ulama hadis pun yang memberi penilaian demikian. Namun demikian, dalam jalur periwayatan tersebut terdapat seorang perawi yang dinilai mubham sehingga mencacatkan hadis tersebut karena tidak diketahuinya kualitas

\footnotetext{
${ }^{4}$ Bahasan tentang kritik matan, lihat Arief Halim, Metodologi Tahqiq Hadis: Secara Mudah dan Munasabah (Malaysia: Universiti Sains Malaysia, 2007), 60.
}

sang perawi. Dengan ini penulis berkesimpulan hadis tersebut daif meski alTirmiżì menilainya sebagai ḥasan.

\section{Makna Kandungan Hadis}

a. Pengertian Sabar

Asal usul kata "sabar" ialah alman' $u$ (menahan) dan al-ḥabsu (mencegah). Jadi sabar secara singkat ialah menahan jiwa dari dari cemas, lisan dari mengeluh dan organ tubuh dari menampar pipi, merobek robek baju. Al-syiddah (kokoh) dan al-quwwah (kekuatan) serta aljam ' $u$ (menggabungkan) dan al-dammu (menghimpun), sabar maka orang sabar ialah orang yang menggabungkan dirinya dan menghimpun dari keluh kesah dan cemas. ${ }^{5}$

"Sabar" berasal dari bahasa Arab dengan berbagai bentuknya șabara, yuṣbiru, șabran, yang berarti bersabar, tabah hati berani atas sesuatu, atau șabirun, atau așābir, șabūr, yang berarti yang sabar, yang tabah hati. ${ }^{6}$ Ṣabbarahu, aṣabarah yang berarti yang menyabarkan, menabahkan hatinya șābarahu, muṣābaratan yang berarti mengalahkannya

${ }^{5}$ Syamsuddin Muhammad bin Abu Bakar Ibn Qayyim al-Jauziyah, Umdatush Shabirin wa Dhakiratisy Shabirin (Sabar Perisai Seorang Mukmin), terj. Fadli, cet. I (Jakarta: Pustaka Azzam, $1420 \mathrm{H}), 19-20$.

${ }^{6}$ Al-Jauziyah, Umdatush, 19-20. 
dalam kesabaran, dan al-șabr yang berarti hal sabar, tabah hati, tetap hati. ${ }^{7}$

Kata "sabar" dalam bahasa Arab terambil dari akar kata yang terdiri hurufhuruf $s a, b a$ dan ra. Maknanya berkisar pada tiga hal yaitu pertama, menahan, kedua, ketinggian sesuatu dan ketiga sejenis batu. Dalam makna menahan, lahir makna konsisten/bertahan, karena yang bertahan menahan pandangannya pada satu sikap. Seorang yang menahan gejolak hatinya dinamai sabar, yang ditahan dipenjara sampai mati dinamai maṣbūrah. Dari makna kedua lahir kata șubr yang berarti puncak sesuatu dan dari makna ketiga, muncul kata al-ṣubrah yakni batu yang kukuh lagi kasar, atau potongan besi. Secara Istilah, sabar ialah menahan diri dalam menanggung suatu penderitaan, baik dalam menemukan sesuatu yang tidak diingini ataupun dalam bentuk kehilangan sesuatu yang disenangi. ${ }^{8}$ Sementara dalam batasan lain, sabar merupakan kata umum yang memiliki arti yang berbeda-beda sesuai dengan obyek yang dihadapinya. Maka ia disebut "sabar" lawannya al-jaza' (gelisah) tetapi sabar dalam perjuangan disebut syajā'ah, lawannya al-jubn (takut). Menahan sesuatu yang mengkhawatirkan disebut rahb al-șadr (lapang dada)

\footnotetext{
${ }^{7}$ Mahmud Yunus, Kamus Arab Indonesia (Jakarta: PT. Hidakarya Agung, 1989), 211.

${ }^{8}$ Dewan Redaksi, Ensiklopedi Islam, jilid IV, cet. III (Jakarta: PT. Ictiyar Baru Van Hoeve, 1994), 184.
}

lawannya al-dajjār (cemas). Menahan bicara disebut kitman (sembunyi) lawannya al-mazl (terbuka). ${ }^{9}$

\section{Quraish Shihab memandang} bahwa kata "sabar" diartikan sebagai menahan baik dalam pengertian fisikmateril, seperti menahan seseorang dalam tahanan (kurungan) maupun immaterialnon fisik seperti menahan diri (jiwa) dalam menghadapi sesuatu yang diinginkannya. Kemudian dari akar tersebut diperoleh sekian bentuk kata dengan arti yang beragam antara lain bermakna menjamin yaitu pemuka masyarakat yang melindungi kaumnya, atau berarti gunung yang tegar dan kukuh, awan yang berada di atas awan lainnya sehingga melindungi apa yang terdapat di bawahnya. Batu-batu yang kukuh, tanah yang gersang, sesuatu yang pahit atau menjadi pahit dan lain-lain. Maka dari sini ia menyimpulkan bahwa kesabaran menuntut ketabahan dalam menghadapi sesuatu yang sulit, berat, dan pahit yang harus diterima dan dihadapi dengan penuh tanggung jawab. Jadi sabar ialah menahan diri atau membatasi jiwa dari keinginannya demi mencapai sesutu yang baik atau lebih baik (luhur). ${ }^{10}$

\footnotetext{
${ }^{9}$ Salman Harun, eds., Ensiklopedia Alquran Kajian Kosa Kata dan Tafsirnya (Jakarta: PT. Intermasa, 1997), 349.

${ }^{10}$ M. Qurash Shihab, Secercah Cahaya Ilahi Hidup Bersama Alquran, cet. I (Bandung: PT. Mizan Pustaka, 2007), 165-166.
} 
Dalam batasan lain, "sabar" terbagi dalam dua yaitu sabar jasmani dan sabar rohani. Sabar jasmani adalah kesabaran dalam menerima dan melaksanakan perintah-perintah kegamaan yang melibatkan anggota tubuh, seperti sabar dalam melaksanakan ibadah haji yang mengakibatkan keletihan atau sabar dalam peperangan termasuk sabar dalam menerima cobaan-cobaan yang menimpa jasmani, seperti penganiayaan, penyakit dan semacamnya. Berbeda dengan sabar rohani ialah sabar yang berkenaan dengan kemampuan menahan kehendak nafsu yang dapat mengakibatkan keburukan seperti menahan amarah atau nafsu seksual yang bukan pada tempatnya. ${ }^{11}$

Adapun beberapa pandangan mengenai pengertian sabar, antara lain:

1. Salah satu akhlak yang mulia yang menghalangi munculnya tindakan yang tidak baik dan tidak memikat.

2. Salah satu kekuatan jiwa dan dengannya segala urusan jiwa menjadi baik dan tuntas.

3. Meneguk sesuatu yang pahit tanpa merasa memberungut.

4. Menjauhi larangan, tenang ketika menengguk musibah, dan menampakkan dirinya kaya pada hal ia miskin harta.

5. Menghadapi musibah dengan akhlak yang baik.

\footnotetext{
${ }^{11}$ Harun, eds., Ensiklopedia, 401.
}

6. Tegar dalam hukum-hukum Allah.

7. Meminta pertolongan kepada Allah swt.

8. Tidak membedakan antara nikmat dan ujian disertai dengan ketentraman hati di dalam menjalani keduanya. ${ }^{12}$

Definisi dan pandangan mengenai sabar sebagaimana di atas, sepertinya sabar merangkum tiga elemen di dalamnya yaitu kesempitan, penderitaan dan dalam peperangan seperti ayat berikut ini:

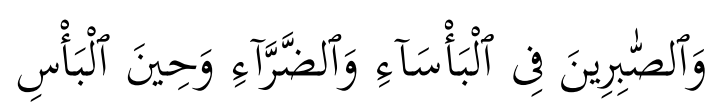

Dan orang orang yang sabar dalam kesempitan, penderitaan dan dalam peperangan. ${ }^{13}$

\section{b. Dimensi-Dimensi Sabar}

Dari berbagai ayat-ayat yang berkenaan dengan ayat ayat yang berkenaan dengan sabar sebagaimana yang disebutkan dalam Alquran dan Hadis menganjurkan untuk bersabar dengan konteks yang berbeda-beda, misalnya dalam surah alBaqarah/2 ayat 45 .

Dalam tafsir Jalālayn menjelaskan ayat ini bahwa untuk meminta pertolongan dalam menghadapi purusan atau kesulitankesulitan harus dengan jalan bersabar atau menahan diri dari hal-hal yang tidak baik melalui salat. Pada ayat ini untuk menyatakan bagaimana pentingnya salat

\footnotetext{
${ }^{12}$ Al-Jauziyah, Umdatush, 21-22.

${ }^{13}$ Departemen Agama RI, Alquran dan Terjemahnya (Jakarta: Yayasan Penterjemah AlQur'an, 1977).
} 
itu. Sebagaimana hadis disebutkan bahwa jika Nabi saw. hatinya risau disebabkan sesuatu masalah, maka beliau segera melakukan salat. Lebih dikemukakan ayat ini ada pula yang mengatakan bahwa perkataan ini ditujukan kepada orang-orang Yahudi yang terhalang beriman disebabkan ketamakan dan ingin kedudukan. Maka mereka diperintahkan bersabar yang maksudnya ialah berpuasa. ${ }^{14}$

Hamka dalam tafsir Al-Azhar menguraikan tentang nasehat kepada pemuka-pemuka Yahudi, untuk merangkul mereka ke dalam suasana Islam supaya meminta pertolongan kepada Allah, pertama dengan sabar, tabah tahan hati dan teguh sehingga tidak berkucak bila datang gelombang kesulitan, maka adalah sabar sebagai benteng. Dengan salat, supaya jiwa itu dekat dan melekat kepada Allah. Orangorang yang terpadu di antara sabarnya dan salatnya akan bersilah hatinya dan berjiwa besar. $^{15}$

M. Quraish Shihab menafsirkan ayat tersebut di atas sebagai langkah meraih khusyuk, ia mengurai dalam menghadapi hidup ini kesabaran dan salat merupakan dua hal yang amat mutlak guna meraih

\footnotetext{
${ }^{14}$ Muhammad bin Ahmad 'Abd al-Rahman bin Ab̄̄ Bakr al-Maḥalī dan al-Suyūtī, Tafsīr Jalālayn, juz. I, cet. I (Kairo: Dār al-Ḥad̄ìs, t.th.), 11.

${ }^{15}$ Hamka, Tafsir Al-Azhar, juz I, cet. III (T.t.: Yayasan Nurul Islam, 1981), 246.
}

sukses dan keduanya pun tidak mudah dikerjakan kecuali bagi yang khusyuk. ${ }^{16}$

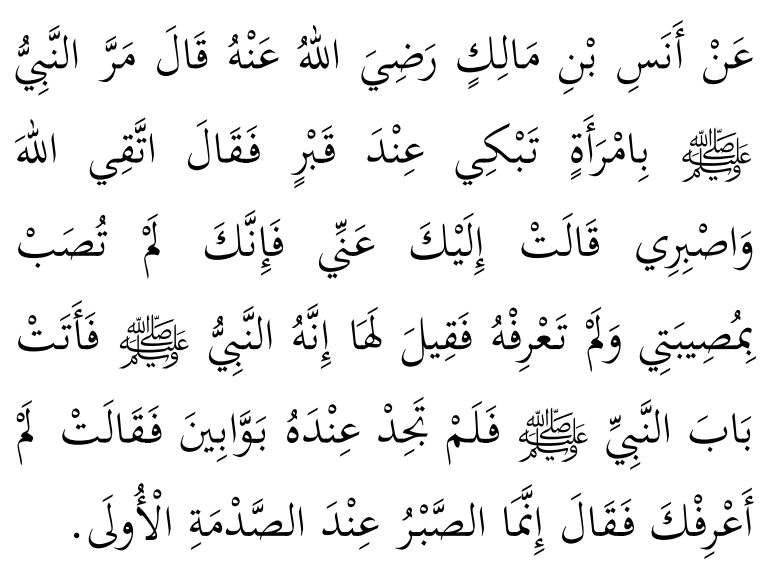

Dari Anas bin Mālik ra. dia berkata: Nabi saw. melewati seorang wanita yang sedang menangis di sisi kuburan maka beliau bersabda bertakwalah kepada Allah dan bersabarlah. Wanita itu berkata: "Menjauh-lah dariku karena sesunguhnya engkau tidak mendapatkan musibah seperti yang ku hadapi." Wanita itu belum mengetahui beliau, maka dikatakan kepadanya, sesung-guhnya ia adalah Nabi saw, lalu wanita itu datang kepada Nabi saw dan tidak menemukan penjaga pintu, lalu dia berkata: "Aku belum mengenalmu." Nabi saw. bersabda: "Sesung-guhnya kesabaran itu adalah pada awal terjadinya musibah."

Sesungguhnya kesabaran itu adalah pada awal musibah (pada awal terjadinya musibah). Imam Muslim juga menukil lafal serupa. Maksudnya apabila kita bersikap tenang ketika terjadi hal-hal menimbulkan kepanikan dalam hati, maka itulah kesabaran yang berhak mendapatkan pahala.

\footnotetext{
${ }^{16}$ M. Quraish Shihab, Menabur Pesan Ilahi: Alquran Dan Dinamika Kehidupan Masyarakat, cet. I (Jakarta: Lentera Hati, 2006), 41.
} 
Al-Khattābī berkata bakwa

kesabaran yang terpuji adalah kesabaran saat tertimpa musibah secara tiba-tiba berbeda dengan kejadian kejadian selanjutnya, di mana musibah itu pun akan dilupakan seiring dengan bergantinya hari. Al-Khattābī meriwayatkan dari ulama selainnya bahwa seorang tidak diberi pahala karena musibah yang menimpanya, sebab itu tidak termasuk perbuatannya. Akan tetapi ia diberi pahala karena sikap dan kesabarannya.

Ibnu Battāa berkata, bahwa beliau menginginkan agar tidak terkumpul musibah karena kematian dan musibah karena kehilangan pahala, sedangkan alṬaybī berpendapat perkataan ini merupakan jawaban dari beliau Saw. telah menempuh sikap bijak seakan-akan beliau bersabda: “Tinggalkanlah alasan itu, karena sesungguhnya aku tidak marah kepada sesuatu bukan karena Allah dan perhatikanlah dirimu."

Ibnu al-Manayyār mengatakan bahwa hikmah sehingga Nabi memberi jawaban demikian kepada wanita itu adalah karena wanita itu patuh datang dengan penuh ketakwaan dan kesabaran, serta mengemukakan alasan atas perkataannya yang terucap akibat kesedihan yang menimpanya. Maka Nabi Saw. menjelaskan kepadanya bahwa semestinya kesabaran ini ada pada awal mula terjadinya musibah karena itulah yang berhak mendapatkan pahala.

Pendapat ini didukung oleh riwayat Abū Hurayrah yang telah disebutkan bahwa wanita itu berkata aku bersabar ... aku bersabar juga didukung oleh riwayat mursal Yaḥyā bin Abī Kasīir yang telah dikutip sebelumnya, Beliau mengatakan: "Pergilah karena sesungguhnya kesabaran adalah ketika awal musibah." 'Abd al-Razzāq dari riwayat mursal, al-Hasan menambahkan bahwa 'ibrah (pelajaran) tidak dimiliki oleh keturunan Adam. ${ }^{17}$

\section{Kesimpulan}

Berdasarkan dari hasil pembahasan tentang kesabaran dalam perspektif hadis sebagaimana telah dikemukakan terdahulu, maka dapat disimpulkan bahwa kesabaran bukan berarti "lemah" dan "pasrah" atau menerima apa adanya,tetapi ia merupakan perjuangan yang menggambarkan kekuatan jiwa pelakunya (mengendalikan) keinginan hawa nafsu sehingga urgensi kesabaran bagi setiap muslim terletak pada situasi dan kondisi apa pun dihadapi dengan kata lain kesabaran saja dibutuhkan ketika menghadapi kebutuhan ketika menghadapi kesulitan atau malapetaka, tetapi kesabaran juga dibutuhkan ketika menghadapi kesuksesan atau kebahagiaan.

${ }^{17}$ Ibn Hajar al-‘Asqalānī, Fath al-Bārī: Syarh Sahịh al-Bukhārrī, jilid 3 (Riyad: Maktabah Dār alSalām, 1997), 116-117. 
Kata sabar memiliki aspek yang erat dengan iman, takwa, dan amal saleh dalam hal ini justru iman dan sabar mengandung nilai optimisme didalam menghadapi kesulitan dan problematika kehidupan adalah mereka yan bertakwa dan orang yang termasuk dalam kategori bertakwa adalah mereka yang senantiasa aktif melakukan amal saleh.

Dari kajian hadis mawdī' $\bar{\imath}$ yang berpokus pada masalah sabar berimplikasi positif terhadap pentingnya memahami sekaligus menghayati makna kesabaran, urgensi kesabaran dan wujud kesabaran serta kaitannya dengan iman dan takwa plus amal saleh.

Dengan begitu, maka disarankan kepada setiap kaum muslimin untuk senantiasa mensosialisasikan kesabaran tersebut dalam dirinya sebagaimana yang dikehendaki oleh hadis, agar tercapai kebahagiaan dan kesejahteraan hidup baik di dunia ini lebih-lebih di akhirat kelak.

\section{Daftar Pustaka}

al-'Asqalānī, Ibn Ḥajar. Fatḥ al-Bārī: Syarh Ṣaḥ̄ḥ al-Bukhārī. Jilid 3. Riyad: Maktabah Dār al-Salām, 1997.

Departemen Agama RI. Alquran dan Terjemahnya. Jakarta: Yayasan Penterjemah Alquran, 1977.

Dewan Redaksi. Ensiklopedi Islam. Jilid IV. Cet. III. Jakarta: PT. Ictiyar Baru Van Hoeve, 1994.

Halim, Arief. Metodologi Tahqiq Hadis: Secara Mudah dan Munasabah. Malaysia: Universiti Sains Malaysia, 2007.

Hamka. Tafsir Al-Azhar. Juz I. Cet. III. T.t.: Yayasan Nurul Islam, 1981.

Harun, Salman. Eds. Ensiklopedia Alquran Kajian Kosa Kata dan Tafsirnya. Jakarta: PT. Intermasa, 1997.

al-Jauziyah, Syamsuddin Muhammad bin Abu Bakar Ibn Qayyim. Umdatush Shabirin wa Dhakiratisy Shabirin (Sabar Perisai Seorang Mukmin), terj. Fadli. Cet. I. Jakarta: Pustaka Azzam, $1420 \mathrm{H}$.

al-Khațīb, Muḥammad 'Ajjāj. Ușūl al-Hadīis: 'Ulūmuhu wa Muṣtalaḥuh. Beirut: Dār al-Fikr, 1989. 
Muḥammad bin Aḥmad 'Abd al-Raḥman bin Ab̄̄ Bakr al-Maḥalī dan al-Suyūtī. Tafsīr Jalālayn. Juz. I. Cet. I. Kairo: Dār al-Hadīì, t.th.

al-Ṣāliḥ, Șubḥī. 'Ulūm al-Hadīs wa Muștalaḥuh. Beirut: Dār al-'Ulūm li al-Malāyīn, 1988.

Shihab, M. Quraish. Menabur Pesan Ilahi: Alquran Dan Dinamika Kehidupan Masyarakat. Cet. I. Jakarta: Lentera Hati, 2006.

. Secercah Cahaya Ilahi Hidup Bersama Alquran. Cet. I. Bandung: PT. Mizan Pustaka, 2007.

Yunus, Mahmud. Kamus Arab Indonesia. Jakarta: PT. Hidakarya Agung, 1989. 